\title{
Internal Calibrant for an Exact Mass Measurement in Electrospray Ionization Mass Spectrometry
}

\author{
Kentaro Yamaguchi*๋, Shigeru SaKamoto*, Tsuneo Imamoto** and Tsutomu Ishikawa*** \\ *Chemical Analysis Center, Chiba University, Yayoi-cho, Inage, Chiba 263-8522, Japan \\ **Department of Chemistry, Faculty of Science, Chiba University, \\ Yayoi-cho, Inage, Chiba 263-8522, Japan \\ ***Faculty of Pharmaceutical Sciences, Chiba University, Yayoi-cho, Inage, Chiba 263-8522, Japan
}

Keywords Electrospray, mass spectrometry, internal calibrant

An exact mass measurement in electrospray ionization mass spectrometry (ESI-MS) has been applied to determine the molecular composition of some large organic molecules. ${ }^{1}$ However, a general and suitable internal calibrant has not yet been reported. Although polyglycols and polyethyleneglycols have been considered to be promising calibrants, it is generally difficult to obtain the desired ion intensity and mass number using these polymers. Almost all calibrants have been used as independently measured external standards to avoid any mixing up with the analyte in solution. ${ }^{2}$ Since recent advanced ESI has made it possible to generate various multiply charged molecular ions in the low-mass region ${ }^{3-5}$, an exact mass measurement for large organic molecules has become more adaptable.

We directed our attention to some macrocyclic polyethers, crown ether compounds, and consequently found that these exhibited excellent performance as an internal calibrant for an exact mass measurement in ESI-MS. Sixteen different crown ethers (Table 1) were prepared for measurements.

Each crown ether afforded the adducts with an alkali metal ion, such as $\mathrm{Na}^{+}, \mathrm{K}^{+}, \mathrm{Rb}^{+}$and $\mathrm{Cs}^{+}$, provided in the same manner ${ }^{6}$ and thus the extending variety of calibrants. A total of 64 crown ethers covering a mass range of up to $733 \mathrm{u}$ were prepared. These crown ethers exhibited no interference with the analyte appearing in the mass spectrum in the case that the sample solution was mixed up with different kinds of calibrants and their adducts. ${ }^{7}$ A made-to-order response by adjusting the concentration of each compound was obtained. ${ }^{8}$ This is ascribed to the supreme ionization ability of crown ethers in the positive ESI process. These internal calibrants were used for the exact mass measurements of several compounds. The instrumentation and experimental conditions for the ESI-MS are given in Table 2 .

\footnotetext{
† To whom correspondence should be addressed.
}

The typical spectra in the case of cinchonine (Fig. 1), reserpine (Fig. 2) and angiotensin I (Fig. 3) are shown. A couple of calibrant ion peaks were selected to calibrate the target ion. The target ion peak should be located between these two calibrant ion peaks on the mass spectrum.

As can be seen in Figs. 1 - 3, a deviation in the measured mass number is observed at less than $10 \mathrm{ppm}$ for each compound. This result suggests the excellent capability of these crown ethers used as an internal cal-

Table 1 Exact mass number (amu) of crown ethers

\begin{tabular}{|c|c|c|c|}
\hline $\begin{array}{l}\text { Na:199.0946 } \\
\text { K :215.0686 } \\
\text { Rb:261.0167 } \\
\text { Cs:309.0103 }\end{array}$ & $\begin{array}{l}\mathrm{Na}: 243.1208 \\
\mathrm{~K}: 259.0948 \\
\mathrm{Rb}: 305.0429 \\
\mathrm{Cs}: 353.0365\end{array}$ & $\begin{array}{l}\mathrm{Na}: 287.1471 \\
\mathrm{~K}: 303.1201 \\
\mathrm{Rb}: 349.0691 \\
\mathrm{Cs}: 397.0627\end{array}$ & $\begin{array}{l}\text { Na:291.1208 } \\
\mathrm{K}: 307.0948 \\
\mathrm{Rb}: 353.0429 \\
\mathrm{Cs}: 401.0365\end{array}$ \\
\hline $\begin{array}{l}\mathrm{Na}: 335.1471 \\
\mathrm{~K}: 351.1210 \\
\mathrm{Rb}: 397.0691 \\
\mathrm{Cs}: 445.0627\end{array}$ & $\begin{array}{l}\mathrm{Na}: 383.1471 \\
\mathrm{~K}: 399.1210 \\
\mathrm{Rb}: 445.0691 \\
\mathrm{Cs}: 493.0627\end{array}$ & $\begin{array}{l}\mathrm{Na}: 395.2410 \\
\mathrm{~K}: 411.2149 \\
\mathrm{Rb}: 457.1630 \\
\mathrm{Cs}: 505.1566\end{array}$ & $\begin{array}{l}\mathrm{Na}: 465.2729 \\
\mathrm{~K}: 481.2469 \\
\mathrm{Rb}: 527.1950 \\
\mathrm{Cs}: 575.1886\end{array}$ \\
\hline $\begin{array}{l}\mathrm{Na}: 471.1995 \\
\mathrm{~K}: 487.1734 \\
\mathrm{Rb}: 533.1215 \\
\mathrm{Cs}: 581.1152\end{array}$ & $\begin{array}{l}\mathrm{Na}: 483.1784 \\
\mathrm{~K}: 499.1523 \\
\mathrm{Rb}: 545.1004 \\
\mathrm{Cs}: 593.0940\end{array}$ & $\begin{array}{l}\mathrm{Na}: 483.2934 \\
\mathrm{~K}: 499.2673 \\
\mathrm{Rb}: 545.2154 \\
\mathrm{Cs}: 593.2091\end{array}$ & $\begin{array}{l}\mathrm{Na}: 495.2723 \\
\mathrm{~K}: 511.2462 \\
\mathrm{Rb}: 557.1943 \\
\mathrm{Cs}: 605.1879\end{array}$ \\
\hline $\begin{array}{l}\text { Na:535.2097 } \\
\mathrm{K}: 551.1836 \\
\mathrm{Rb}: 597.1317 \\
\mathrm{Cs}: 645.1253\end{array}$ & $\begin{array}{l}\mathrm{Na}: 559.2519 \\
\mathrm{~K}: 575.2259 \\
\mathrm{Rb}: 621.1739 \\
\mathrm{Cs}: 669.1676\end{array}$ & $\begin{array}{l}\mathrm{Na}: 571.2308 \\
\mathrm{~K}: 587.2047 \\
\mathrm{Rb}: 633.1528 \\
\mathrm{Cs}: 681.1465\end{array}$ & $\begin{array}{l}\mathrm{Na}: 623.2621 \\
\mathrm{~K}: 639.2360 \\
\mathrm{Rb}: 685.1841 \\
\mathrm{Cs}: 733.1778\end{array}$ \\
\hline
\end{tabular}

$\mathrm{Na}:[\mathrm{M}+\mathrm{Na}]^{+}, \mathrm{K}:[\mathrm{M}+\mathrm{K}]^{+}, \mathrm{Rb}:[\mathrm{M}+\mathrm{Rb}]^{+}, \mathrm{Cs}:[\mathrm{M}+\mathrm{Cs}]^{+}$. 
Table 2 Instrumentation and experimental conditions for ESI-MS

$\begin{array}{ll}\text { Mass spectrometer } & \text { JMS-700T JEOL } \\ \text { Capillary voltage } & 2.8 \mathrm{kV} \\ \text { Capillary current } & 300-700 \mathrm{nA} \\ \text { Orifice voltage } & 10 \mathrm{~V} \\ \text { Resolution } & 5000 \\ \text { Solvent } & \mathrm{MeOH} \\ \text { Flow rate } & 17 \mu \mathrm{l} / \mathrm{min} \\ \text { Sample concentration } & 0.1 \mathrm{mmol} / 1 \\ \text { Crown ether concentration } & 0.01 \mathrm{mmol} / \mathrm{l}\end{array}$

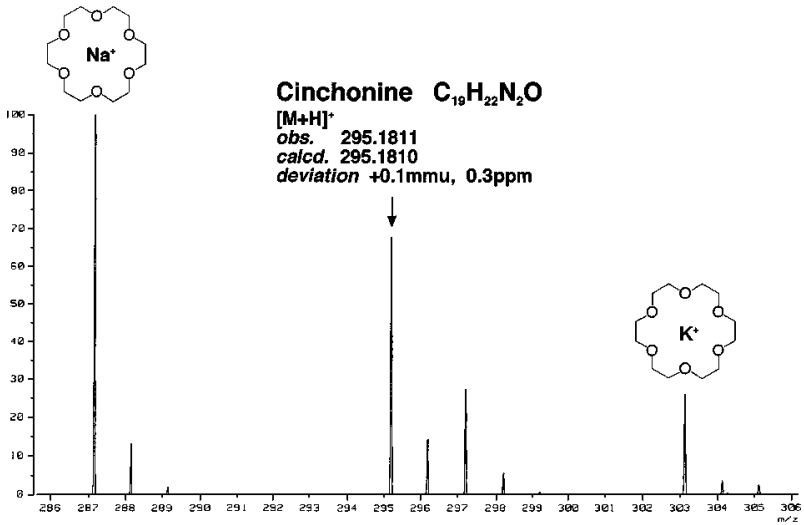

Fig. 1 HR ESI-MS spectrum of cinchonine.

ibrant in ESI-MS. Although the range covered by these experiments is up to $733 \mathrm{u}$ so far, any desired ion peaks will be able to be created in combination with the modified crown ethers. This method is also available for exact mass measurements in other ionization techniques, such as fast atom bombardment (FAB).

\section{References}

1. J. A. Loo, J. X. He and W. L. Cody, J. Am. Chem. Soc., 120, 4542 (1998).

2. L. Jiang and M. Moini, J. Am. Soc. Mass Spectrom., 3, 842 (1992).

3. F. Bitsch, C. O. D.-Buchecker, A.-K. Khemiss, J.-P. Sauvage and A. V. Dorsselaer, J. Am. Chem. Soc., 113, 4023 (1991).

4. C. D.-Buchecker, E. Leize, J.-F. Nierengarten, J.-P.

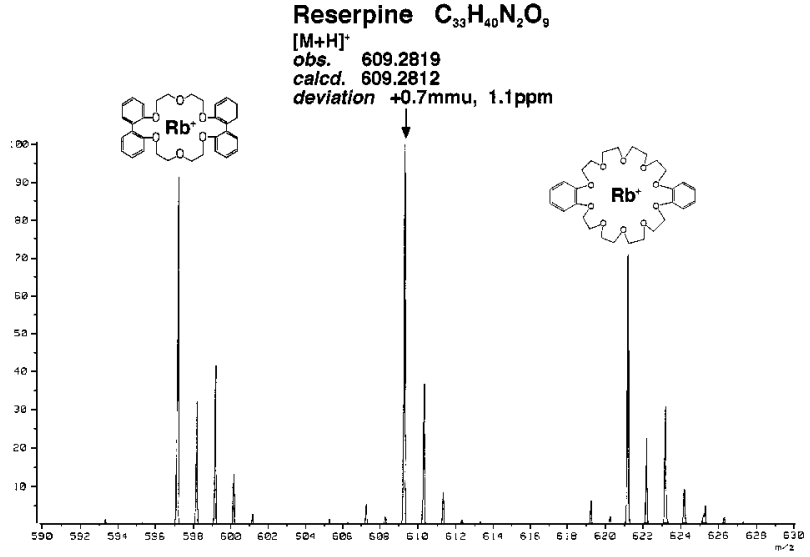

Fig. 2 HR ESI-MS spectrum of reserpine.

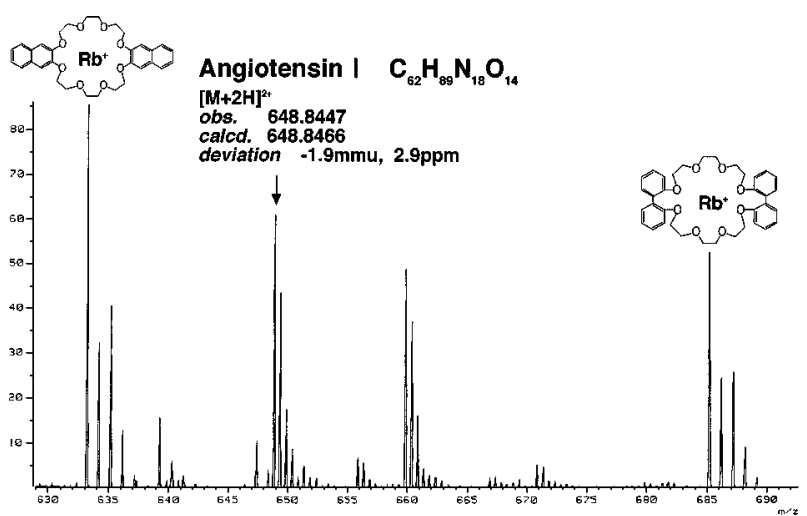

Fig. 3 HR ESI-MS spectrum of angiotensin I.

Sauvage and A. V. Dorsselaer, J. Chem. Soc., Chem. Commun., 1994, 2257.

5. D. Whang, K. -M. Park, J. Heo, P. Ashton and K. Kim, J. Am. Chem. Soc., 120, 4899 (1998).

6. K. Wang, X. Han, R. W. Gross and G. W. Gokel, J. Am. Chem. Soc., 117, 7680 (1995).

7. M. Sawada, Y. Takai, T. Kaneda, R. Arakawa, M. Okamoto, H. Doe, T. Matsuo, K. Naemura, K. Hirose and Y. Tobe, J. Chem. Soc. Chem. Commun., 1996, 1735

8. S. M. Blair, E. C. Kempen and J. S. Brodbelt, J. Am. Soc. Mass Spectrom., 9, 1049 (1998).

(Received May 10, 1999) (Accepted June 30, 1999) 